\title{
Evaluation of Malignant and Pre-Malignant Skin Lesions through Screening Campaigns in a City in the Midwest of Minas Gerais-Brazil
}

\author{
Isabela Guimarães Ribeiro Baêta, Heliomara de Fátima Soares Nunes, Isabella Meira Marcondes, Natália \\ Rodrigues de Oliveira*, Pollyanna Freire Barbosa Lima, Yasmin Emi Enemu Mino and Yuri Gam Faria
} Medical School, Federal University of São João del-Rei, Campus Dona Lindu, Brazil

Submission: August 01, 2020; Published: August 24, 2020

*Corresponding author: Natália Rodrigues de Oliveira, Medical School, Federal University of São João del-Rei, Campus Dona Lindu, Brazil

Abstract

The increasing prevalence of skin cancer worldwide can be understood as the result of excessive exposure to solar radiation. The screening and active search of lesions, as early as its initial phase, has been shown to be the main strategy for secondary prevention and treatment of this disease. Therefore, a voluntary extension project was elaborated with the objective to diagnose and treat the main actinic diseases of the skin. The subsequent article seeks to clarify the main outcomes obtained during this process.

Methods: Experience report of extension project focusing on dermatological consultation, outpatient procedures and referral to specialized services aiming at diagnosis and early treatment of skin cancer.

Results: Nine screening campaigns were conducted, with a total of 332 patients, and $62 \%$ of them had some lesion of premalignant or malignant skin. Among these, the most common lesion was actinic keratosis, followed by basal cell carcinoma, squamous cell carcinoma and melanoma.

Conclusion: It was evidenced that extension projects are useful tools for social transformation, because in addition to social engagement and specialized qualification for academics, it promotes health education for the population and facilitates access to secondary health care.

Keywords: Actinic Lesions; Skin Cancer; Basal Cell Carinoma; Squamous Cell Carcinoma; Melanoma

\section{Introduction}

Exposure to the sun in an inappropriate manner can bring numerous risks to health, including the occurrence of skin cancer (CA), the cancer with the highest incidence in Brazil and in the world. The most common type of skin cancer is basal cell carcinoma (BCC), followed by squamous cell carcinoma (SCC) and melanoma (MM) [1-3]. In the United States of America it's estimated that $20 \%$ of the population will have skin cancer by age 70.3 According to the National Cancer Institute (INCA), approximately 185,000 new cases of the disease are estimated in 2020 in Brazil [1,2]. Skin cancer is basically presented in two forms: melanoma and non-melanoma [4]. The term non-melanoma includes BCC and SCC. BCC consists of cells that resemble the basal cells of the epidermis, but which can also originate from different parts of the follicular apparatus. It may be considered incapable of generating metastasis, however it presents aggressiveness in the local area and the ability to invade and destroy underlying tissues [5]. SCC consists of atypical proliferation of spinous cells, of an invasive quality, which can evolve with metastases. It usually originates from precursor lesions such as solar keratoses and leukoplakia, but can also arise on healthy skin [5]. These precursor lesions are actinic changes of the skin, with potential for malignant transformation. They are mainly caused by ultraviolet (UV) radiation and are markers of chronic sun exposure. Since the effects of UV radiation are cumulative, older people are the most susceptible to its development [6].

Both BCC and SCC are more prevalent in light-skinned people, usually with involvement of photoexposed regions of the body, such as the face, neck, back, forearms and hands [4]. These two types of carcinoma present distinct characteristics on clinical and histopathological examination, but they are similar in prognosis, as they have low lethality and metastases are rare. Although not a threat to life, both carcinomas constitute a major public health 
problem, as they present high morbidity with considerable functional and aesthetic damage to the patient $[1,7]$. According to the INCA, approximately 177,000 new cases of non-melanoma skin cancer are estimated by 2020 and in 2015, 1,958 deaths caused by the disease were recorded [1]. On the other hand, melanoma skin cancer (MM), despite the lower incidence, has high lethality, with a poor prognosis when there is metastasis at diagnosis. It may originate from melanocytic junction or compound nevus (MM "de nevus"), although in about $70 \%$ of cases the previous existence of pigment nevus (MM "de novo") is not reported. In this sense, special importance is attributed to ultraviolet rays in the genesis of melanoma [2]. According to the INCA, in 2020, a total of 8,450 new cases of MM skin cancer were estimated in 2020, and in $2015,1,794$ deaths from this neoplasm were recorded [2]. These numbers reflect the higher aggressiveness of MM when compared to non-melanoma types.

Thus, the early and accurate diagnosis of initial and minor lesions implies lower chances of unsightly deformities/scars and functional impairment in the case of surgical treatment for non-melanoma skin cancer. In the case of melanoma, early diagnosis implies preserving the patient's life, since the presence of metastases is associated with high mortality. In this case, the diagnosis of initial lesions, with a thickness of less than $1 \mathrm{~mm}$, is the main factor for a good prognosis [7]. Therefore, the Academic League of Dermatology (LADERM) of the Federal University of São João del-Rei (UFSJ) - Central-west campus of Dona Lindu (CCO) in partnership with the Association to Combat Cancer in the Midwest of Minas Gerais (ACCCOM) carried out an extension project which had the objective to perform dermatological care to residents of a municipality in the Midwest of Minas Gerais and its macro-region, in order to diagnose pre-malignant and malignant skin lesions early, as well as to treat or refer to services of greater complexity for the appropriate treatment of these cases.

\section{Methodology}

This paper consists of an experimental report of the extension project entitled "Let me see your skin? - Evaluation of actinic lesions and prevention of skin cancer in residents of a city in the Midwest of Minas Gerais and its macro-region". This project was developed between April 2017 and December 2018 by medical students at UFSJ/CCO, under the guidance of a responsible dermatologist professor and with occasional participation from other dermatologists. The activities took place through Saturday visits to ACCCOM, in order to perform dermatological care for skin cancer screening. Initially, 30 vacancies were available per day, however this number increased exponentially with each day of care, due to the great demand. Access to care occurred through two modalities: spontaneous demand, in which the interested parties registered on the ACCCOM website and were later called in order of registration; and through contact with the Town Hall of neighboring municipalities. In this last form of admission, the municipal departments of the region pre-selected patients at higher risk of having skin cancer and scheduled their visits to care.
Before starting the consultation, all patients signed a Free and Informed Consent Form (Appendix 1) and a Permission Term for the Use of Images (Appendix 2), authorizing the use of their data for research purposes. During the consultations, patient data such as age, gender, skin color (according to subjective evaluation of the attendant), previous experiences, family history with the disease and use of sunscreen were collected. Next, the clinical examination of the entire skin was performed to identify not only the lesions complained of, but also possible alterations that have gone unnoticed by the patients. All collected data were reported in the Anamnesis Form (Appendix 3). After the evaluation, patients received guidance on the characteristics of skin lesions predicting malignancy and on the importance of skin protection before UV exposure through the use of sunscreen and appropriate clothing. At the end of the consultations, patients with pre-malignant actinic lesions of the skin underwent cryotherapy [1] a technique in which lesions were destroyed by being frozen with the use of liquid nitrogen. Those with suspected malignancy lesions were referred for material collection (biopsy) [1]. The biopsies were performed by medical students, supervised by the dermatologist professor in charge, in order to respect the principles of the outpatient surgery technique. In the impossibility of immediate treatment, the patients were referred to the plastic surgery service linked to the ACCCOM, with the appropriate orientations. All procedures were offered free of charge to the population. This work did not require submission to the Ethics Committee on Research in Human Beings of the Federal University of São João Del Rei (CEPCO), because this body does not require the analysis of extension projects, due to its charitable nature and social relevance [8].

\section{Results}

Between April 2017 and September 2018, 9 skin cancer screening campaigns were conducted by LADERM members at ACCCOM headquarters, with a total of 332 patients treated. These patients were between 10 and 94 years old, with an average age of 60.5 years (Table 1 ). The predominate number of participants were female: 214 (64.5\%) were women and 118 (35.5\%) were men. Regarding color, the majority, 224 (67.5\%), were white, 58 (17.5\%) mixed-raced, 43 (13\%) blacks and $07(2.1 \%)$ category "others" (Figure 1). Standardized scales for the characterization of prototypes have questionable application to ethnic skins [9], which represent the majority of Brazilian skins [10]. For this reason and due to the logistics of assistance in a joint effort situation, we chose to characterize the sample only by skin color, being classified as "white" those with high risk when subjected to photo exposure (skin, hair and light eyes). Among the patients seen, the majority had some malignant or pre-malignant lesion of skin-206 (62\%). It was observed that 169 patients $(49,7 \%)$ had actinic keratoses; $50(15 \%)$ had BCC; $21(6,3 \%)$ had SCC; and $06(1,8 \%)$ presented MM (Figure 2). The coexistence of actinic keratosis and skin CA occurred in 23 of the patients with BCC (46\%), in 09 of those with SCC $(42,9 \%)$ and in 03 patients with MM (50\%) (Figure 2). 


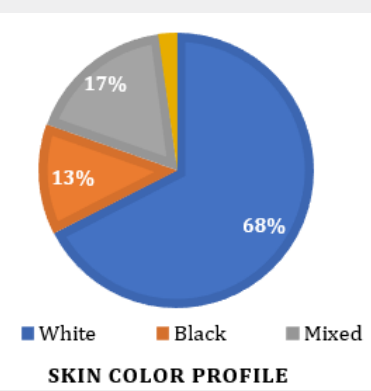

Figure 1: Skin color profile.

SKIN COLOR PROFILE

Figure 1: Skin color profile.

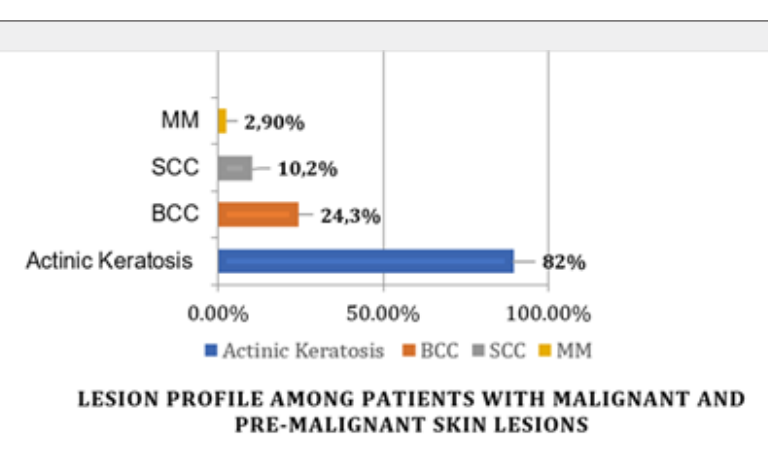

Figure 2: Lession profile among patients with malignant and pre-maligant skin lesions.

Table 1: Number of patients attended by the campaign project.

\begin{tabular}{|c|c|}
\hline \multicolumn{2}{|c|}{ Number of patients attended by the campaign project “Let me see your skin?” } \\
\hline Attendance Date & № of Participants \\
\hline $04 / 29 / 2017$ & 24 \\
\hline $05 / 13 / 2017$ & 22 \\
\hline $06 / 10 / 2017$ & 40 \\
\hline $07 / 01 / 2017$ & 30 \\
\hline $08 / 19 / 2017$ & 44 \\
\hline $09 / 30 / 2017$ & 34 \\
\hline $12 / 2 / 2017$ & 31 \\
\hline $06 / 23 / 2018$ & 38 \\
\hline $09 / 01 / 2018$ & 34 \\
\hline
\end{tabular}

The history of skin cancer in the family was common to 15 (30\%) patients with BCC, 05 (23.8\%) with SCC and 02 (33,3\%) which presented MM. In addition, 14 (28\%) patients with BCC and $04(19 \%)$ patients with SCC revealed a previous history of skin CA.
None of the patients with MM had a personal history of skin cancer. The use of sunscreen was common in 130 patients, corresponding to about $39,2 \%$ of the total patients attended. Among those with skin CA, only $24(31,2 \%)$ used sunscreen daily. In addition, the 
average age of patients with skin CA was 66.3 years, ranging from 41 to 86 for those with BCC, 41 and 91 for those with SCC and 43 and 78 for those with MM. The information related to the profile of the patients assisted (gender, age, skin color, family or personal history of skin cancer) and skin lesions are summarized in Table 2.

Table 2: Profile of the total number of patients assisted in screening campaigns and of patients with malignant and pre-malignant skin lesions.

\begin{tabular}{|c|c|c|c|c|c|c|c|c|c|c|c|c|c|}
\hline \multicolumn{14}{|c|}{ Profile of the total number of patients assisted in screening campaigns and of patients with malignant and pre-malignant skin lesions } \\
\hline \multirow{2}{*}{\multicolumn{2}{|c|}{$\mathrm{n}$}} & \multicolumn{2}{|c|}{ Total } & \multicolumn{2}{|c|}{$\begin{array}{l}\text { Pre-malignant or } \\
\text { malignant lesion }\end{array}$} & \multicolumn{2}{|c|}{ AK } & \multicolumn{2}{|c|}{ BCC } & \multicolumn{2}{|c|}{ SCC } & \multicolumn{2}{|c|}{ MM } \\
\hline & & $\%$ & $\mathrm{n}$ & $\%$ & $\mathrm{n}$ & $\%$ & $\mathrm{n}$ & $\%$ & $\mathrm{n}$ & $\%$ & $\mathrm{n}$ & $\%$ & \\
\hline & Total & 332 & 100 & 206 & 100 & 169 & 100 & 50 & 100 & 21 & 100 & 6 & 100 \\
\hline \multirow{2}{*}{ Gender } & Female & 214 & 64,5 & 121 & 58,7 & 100 & 59,2 & 29 & 58 & 11 & 52,4 & 2 & 33,3 \\
\hline & Male & 118 & 35,5 & 85 & 41,3 & 69 & 40,8 & 21 & 42 & 10 & 47,6 & 4 & 66,7 \\
\hline \multirow{4}{*}{ Skin color } & White & 224 & 67,5 & 149 & 72,3 & 131 & 77,7 & 30 & 60 & 13 & 61,9 & 3 & 50 \\
\hline & Black & 43 & 13 & 20 & 9,7 & 18 & 10,6 & 6 & 12 & 3 & 14,3 & 1 & 16,7 \\
\hline & Mixed-races & 58 & 17,5 & 33 & 16 & 18 & 10,6 & 12 & 24 & 5 & 23,8 & 2 & 33,3 \\
\hline & Others & 7 & 2 & 4 & 2 & 2 & 1,3 & 2 & 4 & - & - & - & - \\
\hline \multirow{3}{*}{ Age } & $<40$ & 30 & 9 & 7 & 3,4 & 6 & 3,5 & - & - & - & - & - & - \\
\hline & $40-60$ & 114 & 34,3 & 59 & 28,6 & 50 & 29,6 & 18 & 36 & 7 & 33,3 & 2 & 33,3 \\
\hline & $>60$ & 188 & 56,7 & 140 & 68 & 113 & 66,9 & 32 & 64 & 14 & 66,7 & 4 & 66,7 \\
\hline \multirow{2}{*}{$\begin{array}{l}\text { Personal history of } \\
\text { skin cancer }\end{array}$} & Present & 70 & 21 & 57 & 27,7 & 49 & 29 & 14 & 28 & 4 & 19 & - & - \\
\hline & Absent & 262 & 79 & 149 & 72,3 & 120 & 71 & 36 & 72 & 17 & 81 & 6 & 100 \\
\hline \multirow{2}{*}{$\begin{array}{l}\text { Family history of } \\
\text { skin cancer }\end{array}$} & Present & 109 & 32,8 & 70 & 34 & 61 & 36 & 15 & 30 & 5 & 23,8 & 2 & 33,3 \\
\hline & Absent & 223 & 67,2 & 136 & 66 & 108 & 64 & 35 & 70 & 16 & 76,2 & 4 & 66,7 \\
\hline \multirow{2}{*}{$\begin{array}{l}\text { Daily use of sun- } \\
\text { screen }\end{array}$} & No & 202 & 60,8 & 124 & 60,2 & 98 & 58 & 33 & 66 & 5 & 23,8 & 4 & 66,7 \\
\hline & Yes & 130 & 39,2 & 82 & 39,8 & 71 & 42 & 17 & 34 & 16 & 76,2 & 2 & 33,3 \\
\hline
\end{tabular}

Subtitle: AK: actinic keratosis; BCC: basal cell carcinoma; SCC: squamous cell carcinoma; MM: melanoma.

\section{Discussion}

The information collected during the visits corroborated the INCA data, which point to a higher prevalence of non-melanoma skin cancer (about 30\%) as well as age being a risk factor for the development of skin lesions ( $\geq 40$ years). The present sample also goes against the trend of reducing the average age of affected individuals, since cases of BCC were found in ages $<30$ [1]. The prevention of skin cancer is based on photoprotective behaviors (e.g., use of sunscreen, clothing and adornments such as hats and sunglasses) and in avoiding risky behaviors (e.g., avoiding burns and tanning) [11]. However, the literature indicates that the use of such measures is neglected by the population,12 as could also be observed by this study, which pointed out that the majority of those attended (60\%) did not use sunscreen, and among individuals diagnosed with skin cancer, this proportion increased to $70 \%$. Among the possible justifications for this fact, "do not deem necessary" and are "unprepared" to protect the skin (for example, through forgetfulness) were common barriers in the use of sunscreen [12]. In addition, it is worth mentioning the high cost of sunscreens in the Brazilian market. These receive an average value of $R \$ 1.17$ per $\mathrm{mL}$, which may become inaccessible considering the recommended use of $35 \mathrm{~mL} /$ application for an adult of $1.73 \mathrm{~m}$ [13]. This value often does not match the financial reality of a large part of the country's population and does not coalign with the importance of this disease for public health.

In this regard, although there are bills, such as no. 3,730/2004, which has the obligation to supply sunscreens by the Unified Health System (SUS), as well as no 4.027/2012 which treats this product as a mandatory individual protection equipment for professionals working in the open, in practice these bills are often not fulfilled. This demonstrates the low effectiveness of public policies in Brazil for primary prevention of skin cancer [14]. Moreover, accurate and early identification of skin lesions suspected of malignancy is essential to guide appropriate treatment and improve prognosis [15]. However, the evidence is still insufficient to safely conclude that skin cancer screening with visual examination of the skin in the general population can reduce its morbidity or mortality [16]. A systematic review by the U.S. Preventive Services Task Force 
(USPSTF) [17], pointed out that the potential benefits of screening are apparent, but the risks, such as unnecessary procedures and their complications, may not be [18]. However, as new data emerges, it has been shown that there are benefits in targeting the screening of high-risk populations (based on age, personal and family history, physical characteristics, and UV exposure) $[18,19]$. From an economic point of view, a systematic review that looked at the costs of skin cancer in the health system of several countries, including Brazil, showed that early detection programs and skin cancer prevention policies can be cost-effective and even inexpensive for governments in the near future [20]. In addition, it was observed that a trained clinician is able to detect and diagnose skin malignancies through routine visual examination $[18,19]$. This demonstrates the need for further studies to assess the feasibility of screening for skin cancer, and what population profile would benefit from it.

\section{Conclusion}

Skin cancer is a public health problem worldwide. Its early diagnosis is possible and implies a better prognosis to the patient. However, the prevention of this disease is still the best approach strategy and should be stimulated in the population. Given the results presented, it is evident the social transformation that extension projects like this are capable of generating, because in addition to social engagement and qualification in dermatology for the academics, it's possible to education population in matters of health, as well as greater ease of access to secondary health care, earlier identification of comorbidities and, finally, treatment opportunities.

\section{Acknowledgment}

To the Federal University of São João del-Rei (UFSJ) and to the entire ACCCOM team, for the unconditional support so that we could provide a quality service, to the population served, for all the lessons learning and, finally, to the Pro-Rectory of Community Affairs Proex.

\section{Contribution of each author}

All authors contributed equally to patient care, both in consultations and in surgical procedures and cryotherapy, in addition to acting in the preparation of the final text. N.R.O. was also responsible for logistical articulation with ACCCOM. I.G.R.B. acted as coordinator and advisor to the students, following the closure of all consultations and procedures, in addition to correcting the final text.

\section{References}

1. Instituto Nacional do Câncer (Brasil). Câncer de pele não melanoma (2020) INCA, Rio de Janeiro, Brazil.
2. Instituto Nacional do Câncer (Brasil). Câncer de pele melanoma (2020) INCA, Rio de Janeiro, Brazil.

3. Skin Cancer Foundation. Skin cancer facts ans statistics [homepage na Internet]. (2020) Skin Cancer Foundation, Nova York, USA.

4. Sociedad Brasileira de Cirurgia Dermatológica (2020). Câncer de pele. São Paulo, Brazil.

5. Costa TDN, Júnior GLS, Albuquerque RBA, Oliveira ERRS, Batista KRF (2016) Estudo retrospectivo de aspectos epidemiológicos, clínicos e histológicos na neoplasia de pele não melanoma. Rev Bras Cir Cabeça Pescoço 45(1): 1-6.

6. Sociedade Brasileira de Dermatologia. Queratose actínica (2017).

7. Costa CS (2012) Epidemiologia do câncer de pele no Brasil e evidências sobre sua prevenção. Rev Diagn Trat, São Paulo, Brazil p. 3.

8. Comitê de Ética em Pesquisa envolvendo Seres Humanos do Campus Centro Oeste Dona Lindu (CEPCO) (2018).

9. Gupta V, Sharma VK (2019) Skin typing: Fitzpatrick grading and others. Clinics in Dermatology, New Delhi, India, p. 7.

10. Instituto Brasileiro de Geografia e Estatística (IBGE) (2010). Censo Demográfico. Rio de Janeiro.

11. Parsons BG, Green LH, Simonsen SE, Harding G, Grossman D, et al. (2018) Opportunities for skin cancer prevention education among individuals attending a community skin cancer screening in a high-risk catchment area. J Community Health 43(2): 212-219.

12. Auerbach MV, Heckman CJ, Darlow S (2018) To protect or not to protect: examining reasons for sun protection among young women at risk for skin cancer. J Behav Med 41(4): 528-536.

13. Gontijo GT, Pugliesi MCC, Araújo FM (2009) Photoprotection. Surg Cosmet Dermatol 1(4): 186-192.

14. Moura PF, Oliveira CSP, Oliveira CF, Miguel MD (2016) Skin cancer: a public health question. Curitiba: Visão Acadêmica 17(4).

15. Dinnes J, Deeks JJ, Chuchu N, Matin RN, Wong KY, et al. (2018) Visual inspection and dermoscopy, alone or in combination, for diagnosing keratinocyte skin cancers in adults (Review). Cochrane Database Syst $\operatorname{Rev}(12):$ CD011901.

16. David C, Mark E, Garcia F, Matthew, Carol M, et al. (2016) W US Preventive Services Task Force. Screening for skin cancer US Preventive Services Task Force Recommendation Statement. JAMA 316(4): 429435 .

17. Wernli KJ, Henrikson NB, Morrison CC, Nguyen M, Pocobelli G, et al. (2016) Screening for skin cancer in adults - updated evidence report and systematic review for the US Preventive Services Task Force. JAMA 316(4): 436-447.

18. Linos E, Katz KA, Colditz GA (2016) Skin cancer -the importance of prevention. JAMA Intern Med 176(10): 1435-1436.

19. Becevic M (2018) USPSTF: skin cancer screening recommendations. Mo Med 115(6): 517.

20. Gordon LG, Rowel D (2015) Custos do sistema de saúde do câncer de pelee relação custo-benefício da prevenção e rastreamento do câncer de pele. Eur J Cancer Prev 24(2): 141-149. 


\section{Your next submission with Juniper Publishers} will reach you the below assets

- Quality Editorial service

- Swift Peer Review

- Reprints availability

- E-prints Service

- Manuscript Podcast for convenient understanding

- Global attainment for your research

- Manuscript accessibility in different formats

( Pdf, E-pub, Full Text, Audio)

- Unceasing customer service

Track the below URL for one-step submission

https://juniperpublishers.com/online-submission.php 